\title{
Production of Baby Corn as Influenced by Spacing and Nutrient Management
}

\author{
Neelam and Rinjumoni Dutta* \\ Assam Agricultural University, India \\ *Corresponding author
}

\section{A B S T R A C T}

\begin{abstract}
Keywords
Baby corn, Yield attributing

characters, Cob yield, Green fodder yield,

Vermicompost

(VC)

Article Info

Accepted:

12 November 2018

Available Online:

10 December 2018

A field experiment was conducted at Instructional-cum-Research (ICR) Farm, Assam Agricultural University, Jorhat during the summer season, 2017 to study the yield attributing characters and yield of baby corn under spacing viz., $40 \mathrm{~cm}$ x $20 \mathrm{~cm}, 40 \mathrm{~cm} \times$ $25 \mathrm{~cm}, 45 \mathrm{~cm} \times 20 \mathrm{~cm}$ and $45 \mathrm{~cm} \times 25 \mathrm{~cm}$ in main plot and nutrient management practices viz., $120-60-60 \mathrm{~N}-\mathrm{P}_{2} \mathrm{O}_{5}-\mathrm{K}_{2} \mathrm{O}(\mathrm{kg} / \mathrm{ha}), 75 \%$ of $\mathrm{N}$ of $\mathrm{I}_{1}+25 \% \mathrm{~N}$ replaced by $\mathrm{VC}$ and $50 \%$ of $\mathrm{N}$ of $\mathrm{I}_{1}+50 \% \mathrm{~N}$ replaced by VC in sub plot under split-plot design with three replications. Experimental findings revealed that spacing $40 \mathrm{~cm} \times 20 \mathrm{~cm}$ and $45 \mathrm{~cm} \times 20 \mathrm{~cm}$ had significantly higher plant height and leaf area index as compared to $40 \mathrm{~cm} \times 25 \mathrm{~cm}$ and 45 $\mathrm{cm} \times 25 \mathrm{~cm}$ at 45 DAS and at harvest. The yield attributing characters viz., number of cobs per plant, weight of cob and length of cob with and without husk and girth of baby corn were found maximum under spacing $45 \mathrm{~cm} \times 25 \mathrm{~cm}$ with application of $75 \%$ of $\mathrm{N}$ of $\mathrm{I}_{1}+$ $25 \%$ N replaced by VC. Significantly highest cob yield with husk, cob yield without husk and green fodder yield was obtained under spacing $45 \mathrm{~cm}$ x $20 \mathrm{~cm}$ and treatment $75 \%$ of N of $\mathrm{I}_{1}+25 \% \mathrm{~N}$ replaced by $\mathrm{VC}$ as compared to all other treatments.
\end{abstract}

\section{Introduction}

Maize (Zea mays L.) is called as miracle crop and is third most important crop in the world among cereals after wheat and rice. With the rise in standards of living and advancement in science and technology, there is a change in the traditional usage of maize as food and increase in the consumption of green ears as food especially in cities and towns, for that "Baby corn" is a profitable crop that allows a diversification of production, aggregation of value and increased income (Pandey et al., 2002). Baby corn as the name implies, is not genetically dwarf maize but it is the immature ear of normally grown maize harvested within 2-3 days of silking. In Indian agriculture, baby corn assumes special significance on account of its utilization as food, feed and fodder besides several industrial uses.

Among the different agronomic practices, crop geometry is considered as one of the most important factors to harvest maximum solar radiations and utilizes the soil resources effectively and in turn better photosynthate formation. Though the spacing requirement has been standardized for grain and fodder 
maize, the information on the influence of spacing on yield of baby corn composite is still obscure. Another important aspect for getting better yield of baby corn is the proper nutrient management system. As a heavy feeder of nutrients, its productivity is largely dependent on nutrient management. Chemical fertilizers are the primary source of plant nutrients. Their application may assist in obtaining maximum production of baby corn, but the excessive use of chemical fertilizers has been associated with decline in soil physical and chemical properties and crop yield (Kumar et al., 2016). Organic manure induces improvement in soil physical, chemical and biological properties. Combine application of both organic and inorganic fertilizer to maintain soil fertility and productivity is the best alternative. The organic fertilizers such as vermicompost besides supplying $\mathrm{N}, \mathrm{P}$ and $\mathrm{K}$ also make unavailable sources of elemental nitrogen, bound phosphates, potassium, micronutrient and decomposed plant residue into available form to facilitate plant to absorb the nutrients over a long period of time. In India, more attention is now given to explore its potentials in order to mend the economic stability of the growing farmers. Management methods that decrease the requirement for agricultural chemicals are needed in order to avoid adverse environment impacts. The study was designed by concentrating on the above points to standardize the spacing and nutrient requirement for maximizing the production of baby corn.

\section{Material and Methods}

The field experiment was carried out at the Instructional-cum-Research (ICR) Farm, Assam Agricultural University, Jorhat-13 during the summer season of 2017. The site is situated at $26^{\circ} 47^{\prime} \mathrm{N}$ latitude and $94^{\circ} 12^{\prime} \mathrm{E}$ longitude with an altitude of 86.56 meter above the mean sea level. The baby corn variety VL-78 was used as test crop. The sowing of crop was done on $7^{\text {th }}$ March, 2017. The soil of experimental site was sandy loam in texture, acidic in reaction, medium in organic carbon $(0.72 \%)$, low in available $\mathrm{N}$ $(224.12 \mathrm{~kg} / \mathrm{ha})$ and medium in available $\mathrm{P}_{2} \mathrm{O}_{5}$ $(24.48 \mathrm{~kg} / \mathrm{ha})$ and $\mathrm{K}_{2} \mathrm{O}(161.32 \mathrm{~kg} / \mathrm{ha})$. The treatments consisted of four spacing viz., 40 $\mathrm{cm} \times 20 \mathrm{~cm}\left(\mathrm{~S}_{1}\right), 40 \mathrm{~cm} \times 25 \mathrm{~cm}\left(\mathrm{~S}_{2}\right), 45 \mathrm{~cm} \mathrm{x}$ $20 \mathrm{~cm}\left(S_{3}\right)$ and $45 \mathrm{~cm} \times 25 \mathrm{~cm}\left(S_{4}\right)$ in main plot and three nutrient management practices viz., $120-60-60 \mathrm{~N}-\mathrm{P}_{2} \mathrm{O}_{5}-\mathrm{K}_{2} \mathrm{O}$ (kg/ha) $\left(\mathrm{I}_{1}\right), 75 \%$ of $\mathrm{N}$ of $\mathrm{I}_{1}+25 \% \mathrm{~N}$ replaced by $\mathrm{VC}\left(\mathrm{I}_{2}\right)$ and $50 \%$ of $\mathrm{N}$ of $\mathrm{I}_{1}+50 \% \mathrm{~N}$ replaced by $\mathrm{VC}\left(\mathrm{I}_{3}\right)$ in sub-plot with three replications in split-plot design. The experimental field was first ploughed by tractor drawn disc plough and subsequently two harrowing were done followed by leveling. After the preparatory tillage, the field was laid out in 36 plots of size $13.5 \mathrm{~m}^{2}$ each. The different doses of fertilizers were applied as per the treatments mentioned earlier. Full amount of phosphatic and potassic fertilizer and half amount of nitrogenous fertilizer were applied as uniformly as possible before sowing. The rest half of the nitrogenous fertilizer was applied as top dressing during the time of earthing up. The field was kept free from weeds. Two hand weeding at 25 DAS and 45 DAS were performed. Harvesting of baby corn was done at 2-3 days of silk emergence stage by leaving border rows. Prior to experimentation the land was utilized for growing maize during summer season and potato during rabi season.

\section{Experimental observations recorded}

From each plot five plants were selected randomly leaving the border rows of the plot and the plant height was measured in centimeters at $25 \mathrm{DAS}, 45 \mathrm{DAS}$ and at the harvesting stage from the base of the plant at soil level to the apex of flag leaf. Leaf area index was calculated by the following formula as prescribed by Watson (1952): 
Leaf area index (LAI) $=$ Total leaf area/Ground area

Cobs from five selected plants were counted in each plot and calculated for average value of the number of cobs per plant. Five cobs were selected from each plot and weighed using electric balance and the mean value of the weight of cob with husk and without husk were calculated. Similarly, the length of five randomly selected cobs with husk and without husk from each plot was recorded and the average was worked out. The cobs taken for mean length were also taken to calculate mean girth per cob. The width of each selected cobs without husk was measured as diameter and average girth of baby corn without husk was worked out and expressed in $\mathrm{cm}$. Cobs were picked up from each plot treatment wise and weighed with and without husk for yield estimation. This was then converted to quintal per hectare.

After the picking of cobs, the green plants were allowed to stand in the field for a week. By this time all the plants were cut close to the ground and the total weight of all plants from each plot was taken. Per plot yields was then converted to quintal per hectare. Harvest index is calculated as the ratio of economic yield to total biological yield and expressed in percentage. The harvest index for baby corn was worked out as indicated below:

Harvest index $(\%)=\frac{\text { Economic yield }(\mathrm{q} / \mathrm{ha})}{\text { Total biological yield }(\mathrm{q} / \mathrm{ha})} \times 100$

\section{Statistical analysis}

The data pertaining to various observations were statistically analyzed by the procedure of analysis of variance for split-plot design (SPD) given by Panse and Sukhatma (1985). For significant ' $F$ ' test, critical difference (CD) was reported at 5 per cent probability level.

\section{Results and Discussion}

Effect of spacing and nutrient management on the growth parameters of baby corn

The different spacing treatments has been found to exert a significant difference on crop growth in terms of plant height and leaf area index plant height except during initial stage of growth. The data regarding plant height at 45 DAS and at harvest revealed that $40 \mathrm{~cm} \mathrm{x}$ $20 \mathrm{~cm}$ and $45 \mathrm{~cm} \times 20 \mathrm{~cm}$ spacing had significantly higher plant height as compared to other spacing treatments. The higher plant height in closer spacing might be attributed to increase in competition for sunlight, nutrients, space and water by the plants which coupled with favorable climatic conditions especially temperature might have resulted in maximum plant height. The results are in conformity with the findings of Kunjir et al., (2007) who also recorded higher plant height with closer spacing as compared to wider spacing. Spacing of $40 \mathrm{~cm}$ x $20 \mathrm{~cm}$ had significantly higher leaf area index at 45 DAS and at harvesting as compared to other spacing of 40 $\mathrm{cm} \times 25 \mathrm{~cm}$ and $45 \mathrm{~cm} \times 25 \mathrm{~cm}$ but was statistically at par with spacing $45 \times 20 \mathrm{~cm}$. Higher leaf area index in closer spacing was observed due to increased plant density which accommodates more number of plants and can also be ascribed to lesser value of spacing (Wasnik et al., 2012). The different nutrient management practices also exerted a significant influence on the plant height of baby corn at 45 DAS and at harvest. Maximum plant height of baby corn was recorded under treatment $75 \%$ of $\mathrm{N}$ of $\mathrm{I}_{1}+$ $25 \% \mathrm{~N}$ replaced by VC followed by $50 \%$ of $\mathrm{N}$ of $\mathrm{I}_{1}+50 \% \mathrm{~N}$ replaced by VC (Table 1). It might be due to the decomposition of vermicompost at later stages and had solubilizing effect resulting into the higher availability of nutrients, growth promoting substances and number of beneficial organisms like nitrogen fixing, phosphate 
solubilizing and cellulose decomposing organisms etc. Beneficial effect achieved in $75 \%$ of $\mathrm{N}$ of $\mathrm{I}_{1}+25 \% \mathrm{~N}$ replaced by $\mathrm{VC}$ is due to the stabilization of applied chemical fertilizers with vermicompost in 75 per cent and 25 per cent proportion and subsequent release to fulfill the requirement of growing crop. Similar results were also obtained by Khadtare et al., (2006) and Dadarwal et al., (2009). Similarly, the leaf area index was found to be highest in case of $75 \%$ of $\mathrm{N}_{\text {of }} \mathrm{I}_{1}+$ $25 \% \mathrm{~N}$ replaced by $\mathrm{VC}$ at $45 \mathrm{DAS}$ and at harvest. The increase in leaf area index due to replacement of chemical fertilizers with vermicompost upto 25 per cent might be due to the fact that it improves macro and micro nutrient balance of soil rhizosphere environment which influence the leaf growth and its expansion, resulting in more photosynthesis and ultimately into higher leaf area index. In case of $120-60-60 \mathrm{~N}-\mathrm{P}_{2} \mathrm{O}_{5}-\mathrm{K}_{2} \mathrm{O}$ $(\mathrm{kg} / \mathrm{ha})$, the nutrient losses were more especially through $\mathrm{N}$ leaching, $\mathrm{N}$ volatilization and denitrification which affected the nutrient availability to the plant. These results are in line with the findings of Rasool et al., (2015).

\section{Effect of spacing and nutrient management on the yield attributes of baby corn}

Yield attributing characters like number of cobs per plant, weight and length of cob with as well as without husk and girth of baby corn were differed significantly with variation in the spacing per unit area as shown in Table 2. Number of cobs per plant was significantly higher in $45 \mathrm{~cm} \times 25 \mathrm{~cm}$ spacing as compared to $40 \mathrm{~cm} \mathrm{x} 20 \mathrm{~cm}, 40 \mathrm{~cm} \mathrm{x} 25 \mathrm{~cm}$ and $45 \mathrm{~cm} \mathrm{x}$ $25 \mathrm{~cm}$ spacing. The least number of cobs per plant was observed in $40 \mathrm{~cm} \times 20 \mathrm{~cm}$. Increase in number of cobs per plant with increase in spacing i.e. decrease in plant population might be due to minimum competition among the plants for the absorption of water and nutrients from the soil. This finding is in agreement with Gosavi and Bhagat (2009). The number of cobs per plant also differed significantly due to different nutrient management practices. Wider spacing of $45 \mathrm{~cm} \mathrm{x} 25 \mathrm{~cm}$ also recorded significantly higher values for girth of baby corn, weight of cob with and without husk and length of cob with and without husk as compared to other spacing of $40 \mathrm{~cm} \times 20 \mathrm{~cm}, 40 \mathrm{~cm} \times 25 \mathrm{~cm}$ and $45 \mathrm{~cm} \mathrm{x}$ $20 \mathrm{~cm}$. Wider spacing provided uniform spread of plants because of less crowding which resulted into healthy cobs and thereby increases the weight, length of cob and girth of baby corn. The results are supported by the findings of Thavaprakaash et al., (2008) and Arvadiya et al., (2012) who also reported increase in length of baby corn with increase in spacing. Yield attributes and yield of baby corn were significantly influenced by different nutrient management practices. The maximum number of cobs per plant was recorded in case of $75 \%$ of $\mathrm{N}$ of $\mathrm{I}_{1}+25 \% \mathrm{~N}$ replaced by $\mathrm{VC}$ which was at par with $50 \%$ of $\mathrm{N}_{\text {of }} \mathrm{I}_{1}+50 \% \mathrm{~N}$ replaced by VC. The weight of cob with and without husk, length of cob with and without husk and girth of baby corn was also found highest in $75 \%$ of $N$ of $I_{1}+25 \% \mathrm{~N}$ replaced by VC followed by $50 \%$ of $\mathrm{N}$ of $\mathrm{I}_{1}+50 \% \mathrm{~N}$ replaced by VC as compared to $120-60-60 \mathrm{~N}-$ $\mathrm{P}_{2} \mathrm{O}_{5}-\mathrm{K}_{2} \mathrm{O}(\mathrm{kg} / \mathrm{ha})$. This might be due to the more availability of nutrients in soil and better uptake where integrated application of nutrients was done. These results are in line with Khadtare et al., (2006) and Dadarwal et al., (2009).

\section{Effect of spacing and nutrient management on the yield of baby corn}

Yield of baby corn with and without husk and green fodder yield differed significantly due to different spacing treatments. Yield of the crop is a function of several yield components which are dependent on complementary interaction between vegetative and reproductive growth of the crop. The highest yield of baby corn with and without husk was 
realized with spacing $45 \mathrm{~cm}$ x $20 \mathrm{~cm}$ (Table 2). Under wider spacing of $45 \mathrm{~cm} \times 25 \mathrm{~cm}$, all the yield attributing characters were at their best but due of lesser plant population per unit area, it could not compensate the baby corn yield (with husk and without husk) obtained under spacing $45 \mathrm{~cm} \times 20 \mathrm{~cm}$. Yield of baby corn with husk obtained under $40 \mathrm{~cm} \times 25 \mathrm{~cm}$ was found to be statistically at par with spacing $45 \mathrm{~cm} \times 25 \mathrm{~cm}$. This might be due to more number of plants in spacing $40 \mathrm{~cm} \times 25$ $\mathrm{cm}$ as compared to $45 \mathrm{~cm} \times 25 \mathrm{~cm}$. Under 40 $\mathrm{cm} \times 20 \mathrm{~cm}$ spacing, lower stature of entire yield attributes resulted in the lowest yield of baby corn with husk and without husk. These results are in conformity with the findings of several earlier researchers Arvadiya et al., (2012), Ramchandrappa et al., (2004) and Thavaprakash et al., (2008) (Fig. 1).

Table.1 Effect of spacing and nutrient management on plant height $(\mathrm{cm})$ of baby corn at 25

DAS, 45 DAS and at harvest

\begin{tabular}{|c|c|c|c|c|c|c|}
\hline \multirow[t]{2}{*}{ Treatments } & \multicolumn{3}{|c|}{ Plant height $(\mathrm{cm})$} & \multicolumn{3}{|c|}{ Leaf area index } \\
\hline & $\begin{array}{c}25 \\
\text { DAS }\end{array}$ & $\begin{array}{c}45 \\
\text { DAS }\end{array}$ & $\begin{array}{c}\text { At } \\
\text { harvest }\end{array}$ & $\begin{array}{c}25 \\
\text { DAS }\end{array}$ & $\begin{array}{c}45 \\
\text { DAS }\end{array}$ & $\begin{array}{c}\text { At } \\
\text { harvest }\end{array}$ \\
\hline \multicolumn{7}{|l|}{ Spacing } \\
\hline$S_{1}: 40 \mathrm{~cm} \times 20 \mathrm{~cm}$ & 30.87 & 130.34 & 170.75 & 1.00 & 4.85 & 6.07 \\
\hline$S_{2}: 40 \mathrm{~cm} \times 25 \mathrm{~cm}$ & 32.28 & 127.05 & 167.76 & 1.07 & 4.67 & 5.80 \\
\hline$S_{3}: 45 \mathrm{~cm} \times 20 \mathrm{~cm}$ & 31.65 & 128.98 & 169.46 & 1.02 & 4.82 & 6.02 \\
\hline$S_{4}: 45 \mathrm{~cm} \times 25 \mathrm{~cm}$ & 33.14 & 126.48 & 166.43 & 1.08 & 4.61 & 5.76 \\
\hline S.Em.( $( \pm)$ & 0.60 & 0.80 & 0.85 & 0.06 & 0.04 & 0.07 \\
\hline C.D (0.05) & NS & 2.76 & 2.96 & NS & 0.14 & 0.25 \\
\hline \multicolumn{7}{|l|}{ Nutrient management } \\
\hline $\begin{array}{l}\mathrm{I}_{1}: 120-60-60 \mathrm{~N}-\mathrm{P}_{2} \mathrm{O}_{5}-\mathrm{K}_{2} \mathrm{O} \\
(\mathrm{kg} / \mathrm{ha})\end{array}$ & 33.36 & 124.90 & 163.71 & 1.06 & 4.57 & 5.74 \\
\hline $\begin{array}{l}I_{2}: 75 \% \text { of } N \text { of } I_{1}+25 \% N \\
\text { replaced by } V C\end{array}$ & 32.11 & 132.34 & 173.53 & 1.07 & 4.92 & 6.11 \\
\hline $\begin{array}{l}I_{3}: 50 \% \text { of } N \text { of } I_{1}+50 \% \mathrm{~N} \\
\text { replaced by } V C\end{array}$ & 30.49 & 127.40 & 168.56 & 1.00 & 4.72 & 5.89 \\
\hline S.Em. $( \pm)$ & 0.80 & 1.64 & 2.56 & 0.03 & 0.09 & 0.10 \\
\hline C.D (0.05) & NS & 4.92 & 7.68 & NS & 0.27 & 0.29 \\
\hline Interaction $(\mathrm{S} \times \mathrm{I})$ & NS & NS & NS & NS & NS & NS \\
\hline
\end{tabular}


Table.2 Effect of spacing and nutrient management on number of cobs per plant, length of cob $(\mathrm{cm})$ with husk and without husk, weight of cob (g) with husk and without husk and girth of baby corn $(\mathrm{cm})$

\begin{tabular}{|c|c|c|c|c|c|c|}
\hline \multirow[t]{2}{*}{ Treatments } & \multirow{2}{*}{$\begin{array}{l}\text { Number } \\
\text { of cobs } \\
\text { per plant }\end{array}$} & \multicolumn{2}{|c|}{$\begin{array}{l}\text { Length of cob } \\
(\mathrm{cm})\end{array}$} & \multicolumn{2}{|c|}{ Weight of cob } & \multirow{2}{*}{$\begin{array}{c}\text { Girth of } \\
\text { baby } \\
\text { corn } \\
(\mathrm{cm})\end{array}$} \\
\hline & & $\begin{array}{l}\text { With } \\
\text { husk }\end{array}$ & $\begin{array}{c}\text { Without } \\
\text { husk }\end{array}$ & $\begin{array}{l}\text { With } \\
\text { husk }\end{array}$ & $\begin{array}{c}\text { Without } \\
\text { husk }\end{array}$ & \\
\hline \multicolumn{7}{|l|}{ Spacing } \\
\hline$S_{1}: 40 \mathrm{~cm} \times 20 \mathrm{~cm}$ & 2.34 & 20.25 & 7.95 & 37.04 & 7.33 & 1.61 \\
\hline$S_{2}: 40 \mathrm{~cm} \times 25 \mathrm{~cm}$ & 2.72 & 22.40 & 8.96 & 42.51 & 8.85 & 1.93 \\
\hline$S_{3}: 45 \mathrm{~cm} \times 20 \mathrm{~cm}$ & 2.64 & 21.83 & 8.68 & 41.59 & 8.40 & 1.71 \\
\hline$S_{4}: 45 \mathrm{~cm} \times 25 \mathrm{~cm}$ & 2.89 & 23.44 & 9.14 & 45.86 & 9.73 & 2.02 \\
\hline S.Em. $( \pm)$ & 0.04 & 0.31 & 0.16 & 0.93 & 0.27 & 0.08 \\
\hline C.D (0.05) & 0.15 & 1.08 & 0.54 & 3.23 & 0.92 & 0.29 \\
\hline \multicolumn{7}{|l|}{ Nutrient management } \\
\hline$I_{1}: 120-60-60 \mathrm{~N}-\mathrm{P}_{2} \mathrm{O}_{5}-\mathrm{K}_{2} \mathrm{O}(\mathrm{kg} / \mathrm{ha})$ & 2.48 & 20.42 & 8.00 & 37.25 & 7.31 & 1.68 \\
\hline $\begin{array}{l}\mathrm{I}_{2}: \mathbf{7 5 \%} \text { of } \mathrm{N} \text { of } \mathrm{I}_{1}+25 \% \mathrm{~N} \\
\text { replaced by } \mathrm{VC}\end{array}$ & 2.78 & 23.63 & 9.28 & 45.99 & 9.58 & 1.96 \\
\hline $\begin{array}{l}I_{3}: 50 \% \text { of } N \text { of } I_{1}+50 \% \mathrm{~N} \\
\text { replaced by } \mathrm{VC}\end{array}$ & 2.69 & 21.89 & 8.77 & 42.01 & 8.85 & 1.81 \\
\hline S.Em. $( \pm)$ & 0.03 & 0.47 & 0.17 & 1.26 & 0.22 & 0.07 \\
\hline C.D (0.05) & 0.09 & 1.39 & 0.50 & 3.78 & 0.67 & 0.22 \\
\hline Interaction $(\mathrm{S} \times \mathrm{I})$ & NS & NS & NS & NS & NS & NS \\
\hline
\end{tabular}

Table.3 Effect of spacing and nutrient management on cob yield (q/ha) with husk, cob yield (q/ha) without husk, green fodder yield (q/ha) and harvest index (\%) of baby corn

\begin{tabular}{|c|c|c|c|c|}
\hline Treatments & $\begin{array}{c}\text { Cob yield } \\
\text { with husk } \\
\text { (q/ha) }\end{array}$ & $\begin{array}{c}\text { Cob yield } \\
\text { without } \\
\text { husk (q/ha) }\end{array}$ & $\begin{array}{c}\text { Green } \\
\text { fodder yield } \\
\text { (q/ha) }\end{array}$ & $\begin{array}{l}\text { Harvest } \\
\text { index }(\%)\end{array}$ \\
\hline \multicolumn{5}{|l|}{ Spacing } \\
\hline$S_{1}: 40 \mathrm{~cm} \times 20 \mathrm{~cm}$ & 82.16 & 16.32 & 285.04 & 4.44 \\
\hline$S_{2}: 40 \mathrm{~cm} \times 25 \mathrm{~cm}$ & 84.91 & 17.00 & 281.03 & 4.64 \\
\hline$S_{3}: 45 \mathrm{~cm} \times 20 \mathrm{~cm}$ & 89.93 & 18.65 & 289.08 & 4.92 \\
\hline$S_{4}: 45 \mathrm{~cm} \times 25 \mathrm{~cm}$ & 86.24 & 18.12 & 278.26 & 4.97 \\
\hline S.Em. $( \pm)$ & 1.30 & 0.27 & 1.95 & 0.14 \\
\hline C.D (0.05) & 4.51 & 0.93 & 6.76 & NS \\
\hline \multicolumn{5}{|l|}{ Nutrient management } \\
\hline$I_{1}: 120-60-60 \mathrm{~N}-\mathrm{P}_{2} \mathrm{O}_{5}-\mathrm{K}_{2} \mathrm{O}(\mathrm{kg} / \mathrm{ha})$ & 81.42 & 16.01 & 271.73 & 4.53 \\
\hline$I_{2}: 75 \%$ of $N$ of $I_{1}+25 \% \mathrm{~N}$ replaced by $\mathrm{VC}$ & 90.62 & 19.30 & 294.15 & 5.01 \\
\hline$I_{3}: 50 \%$ of $N$ of $I_{1}+50 \% \mathrm{~N}$ replaced by $\mathrm{VC}$ & 85.38 & 17.26 & 284.18 & 4.68 \\
\hline S.Em. $( \pm)$ & 1.74 & 0.57 & 5.86 & 0.13 \\
\hline C.D (0.05) & 5.21 & 1.70 & 17.56 & NS \\
\hline Interaction (S x I) & NS & NS & NS & NS \\
\hline
\end{tabular}


Fig.1 Cob yield of baby corn with husk and without husk (q/ha) and green fodder yield (q/ha)

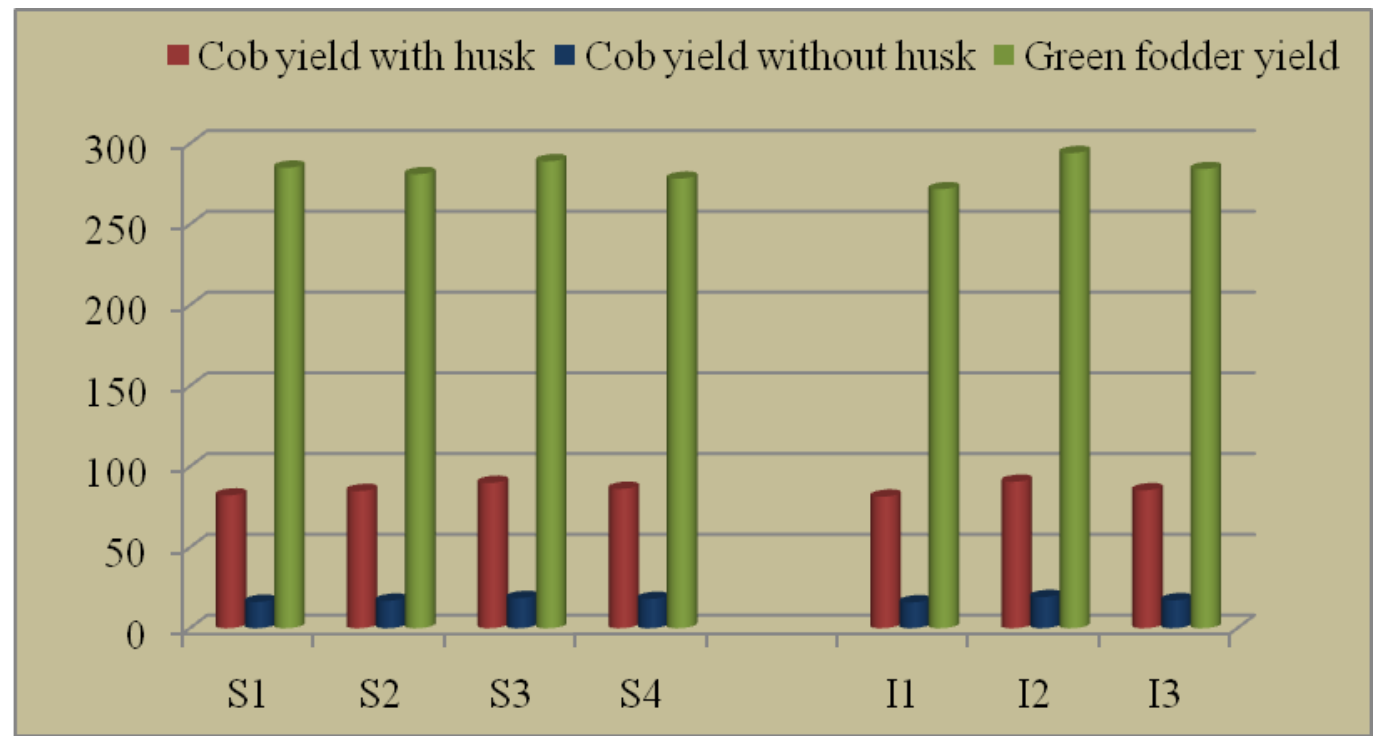

The increased baby corn yield was also due to the better availability of moisture in the soil during the crop growth period. Green fodder yield of baby corn tended to increase with decrease in spacing. The spacing treatment of $45 \mathrm{~cm} \times 20 \mathrm{~cm}$ resulted in higher green fodder yield while wider spacing of $45 \mathrm{~cm} \times 25 \mathrm{~cm}$ resulted in lower green fodder yield (Table 3). The green fodder yield obtained under closer spacing of $40 \mathrm{~cm} \times 20 \mathrm{~cm}$ was lower as compared to $45 \mathrm{~cm} \times 20 \mathrm{~cm}$ but was statistically at par with $45 \mathrm{~cm} \times 20 \mathrm{~cm}$. It might be because of the increased barrenness under $40 \mathrm{~cm}$ x $20 \mathrm{~cm}$ spacing where supply of growth factors such as light, water and nutrients to plants is affected by interaction between the plants and by the efficiency of use of limiting resources. The possible reason for increased yield under spacing $45 \mathrm{~cm}$ x 20 $\mathrm{cm}$ might be due to optimum number of plants per unit area resulting in higher green fodder yield of baby corn which is comparable with spacing $40 \mathrm{~cm} \times 20 \mathrm{~cm}$. The lower green fodder yield was noticed under $45 \mathrm{~cm} \times 25 \mathrm{~cm}$ spacing which was due to lesser number of plants per unit area under this spacing as compared to rest of the treatments. Similar results regarding the green fodder yield of baby corn were reported by Prodhan et al., (2007) and Sukanya et al., (1998) who also envisaged that green fodder yield increased significantly with decrease in spacing i.e. with increase in plant population. The different spacing and nutrient management treatments did not cause any conspicuous effect on harvest index of baby corn.

It can be concluded from the above research findings that crop growth in terms of plant height and leaf area index be better obtained with $40 \mathrm{~cm} \times 20 \mathrm{~cm}$ and $45 \mathrm{~cm} \times 20 \mathrm{~cm}$ spacing with the application of $75 \%$ of $\mathrm{N}$ of $\mathrm{I}_{1}$ $+25 \% \mathrm{~N}$ replaced by VC. For getting better yield attributing characters, baby corn should be sown at wider spacing of $45 \mathrm{~cm} \times 25 \mathrm{~cm}$. However, the best performance of baby corn during the summer season could be achieved with the spacing of $45 \mathrm{~cm} \times 20 \mathrm{~cm}$ with optimum plant population by fertilizing the crop with 120-60-60 N-P $\mathrm{P}_{2} \mathrm{O}_{5}-\mathrm{K}_{2} \mathrm{O} \quad(\mathrm{kg} / \mathrm{ha})$ where $90 \mathrm{~kg} \mathrm{~N}$ is applied through fertilizer + $30 \mathrm{~kg} \mathrm{~N}$ through vermicompost with higher productivity. 


\section{References}

Arvadiya, L. K., Raj, V. C., Patel, T. U and Arvadiya, M. K. 2012. Influence of plant population and weed management on weed flora and productivity of sweet corn. Indian J. Agron. 57(2): 162-167.

Dadarwal, R. S., Jain, N. K. and Singh, D. 2009. Integrated nutrient management in baby corn (Zea mays). Indian J. Agril. Sci. 79(12): 1023-1025.

Gosavi, S. P. and Bhagat, S. B. 2009. Effect of nitrogen levels and spacing on yield attributes, yield and quality parameters of baby corn (Zea mays). Ann. Agric. Res. 30(3 \& 4): 125-128.

Kumar, S., Kumar, A., Singh, J. and Kumar, P. 2016. Growth indices and nutrient uptake of fodder maize (Zea mays L.) as influenced by integrated nutrient management. Forage Res. 42(2): 119123.

Khadtare, S. V., Patel, M. V., Jadhav, J. D. and Mokashi, D. D. 2006. Effect of vermicompost on yield and economics of sweet corn. J. Soils Crops 16: 401406.

Kunjir, S. S.; Chavan, S. A.; Bhagat, S. B. and Zende, N. B. (2007). Effect of planting geometry, nitrogen levels and micronutrients on the growth and yield of sweet corn. Crop Prot. Prod. 2: 2527.

Panse, V. G. and Sukhatma, P. V. 1985. Statistical methods for Agricultural workers. ICAR Publication, New Delhi, pp. 336-340.

Pandey, A. K., Mani, V. P., Ved, Prakash, Singh, R. D. and Gupta, H. S. 2002. Effect of varieties and plant densities on yield, yield attributes and economics of baby corn (Zea mays). Indian J. Agron. 47(2): 221-226.

Prodhan, H. S., Bala, S. and Khoyumthem, P. 2007. Response to rate of nitrogen and effect of plant density on yield of baby corn. J. Interacademica 11 (3): 265269.

Ramachandrappa, B. K., Nanjappa, H. V. and Shivakumar, H. K. 2004. Yield and quality of baby corn (Zea mays L.) as influenced by spacing and fertilizer levels. Acta- Agronomica-Hungarica 52(3): 237-243.

Rasool, S.; Kanth, R.H.; Hamid, S.; Raja, W.; Alie, B.A. and Dar, Z.A. (2015). Influence of integrated nutrient management on growth and yield of sweet corn (Zea mays saccharata) under temperate conditions of Kashmir valley. American J. Expt. Agric. 7(5): 315-325.

Sukanya, T. S., Nanjappa, H. V. and Ramachandrappa, B. K. 1998. Growth parameters and yield of baby corn as influenced by varieties and spacing Mysore. J. Agril. Sci. 32: 264-268.

Thavaprakaash, N., Velayudham, K. and Muthukumar, V. B. 2008. Response of crop geometry, intercropping systems and INM practices on yield and fodder quality of baby corn (Zea mays L.). Asian J. Sci. Res. 1(2): 153-159.

Wasnik, V.K.; Reddy, A.P.K. and Kasbe, Sudhansu, S. (2012). Performance of winter maize under different rates of nitrogen and plant population in Southern Telangana region. Crop Res. 44(3): 269-273.

Watson, D. J. (1952). The physiological basis of variation in yield. Adv. Agron. 4: $101-145$.

\section{How to cite this article:}

Neelam and Rinjumoni Dutta. 2018. Production of Baby Corn as Influenced by Spacing and Nutrient Management. Int.J.Curr.Microbiol.App.Sci. 7(12): 1332-1339. doi: https://doi.org/10.20546/ijcmas.2018.712.162 